\title{
Cultural Mobility, Networks, and Theatre
}

The Stagings of Ibsen's Gengangere (Ghosts) in Berlin, Paris, London, Moscow, New York, and Budapest between 1889 and 1908

\section{ZOLTÁN IMRE}

\begin{abstract}
The Budapest premiere of Henrik Ibsen's Kísértetek (Gengangere) was on 17 October 1908 by the Thália Társaság, a Hungarian independent theatre. Though banned earlier, by 1908, Ibsen's text had already been played all over Europe. Between 1880 and 1908, the search of IbsenStage indicates 402 records, but probably the actual performance number was higher. The popularity of the text can be seen in the fact that all the independent theatres staged it, and most of the famous and less famous travelling companies and travelling stars also kept it in their repertoires. Though, usually, the high-artistic independent and the commercial international and regional travelling companies are treated separately, here, I argue for their close real and/or virtual interconnections, creating such a theatrical and cultural network, in which the local, the regional, the national, and the transnational interacted with and were influenced by each other. At the turn of the nineteenth and twentieth centuries, such interaction among different forces and agents on different levels was one of the special features of cultural mobility (Greenblatt) which characterized intercultural theatre culture, existing in Europe and America, and extending its influence almost all over the globe.
\end{abstract}

\section{KEYWORDS}

Intercultural theatre, touring, theatre historiography, transnationalism, national paradigm, theatrical networks, cultural mobility, independent theatre movement, Théâtre Libre, Freie Bühne, Independent Theatre Society, Московский Художественный театр (MXAT), Thália Társaság.

ISSN 2002-3898

C Zolán Imre and Nordic Theatre Studies

PEER REVIEWED ARTICLE Open access: https://tidsskrift.dk/nts/index

Published with support from Nordic Board for Periodicals in the Humanities

and Social Sciences (NOP-HS)

DOI: $10.7146 /$ nts.v32i2.124345 


\title{
Cultural Mobility, Networks, and Theatre
}

\author{
The Stagings of Ibsen's Gengangere (Ghosts) in \\ Berlin, Paris, London, Moscow, New York, and \\ Budapest between 1889 and $1908^{1}$
}

The Budapest premiere of Henrik Ibsen's Kísértetek (Gengangere) was in 1908 by the Hungarian independent theatre, the Thália Társaság. As an unknown critic remarked, "the Kísértetek is just the play with which the new Thália reintroduced itself. Whether the play, or the popularity of Thália made it - the auditorium was fully packed."2 Although the Thália, due to financial reason, temporarily suspended its activities at the end of 1907, with this premiere, it started again by building a close relation with the workers' movement, often playing in working-class, suburban cultural institutions. Contrary to expectations, the premier did not cause a scandal. By then, Ibsen's text had already been played all over Europe and become famous or at least notorious, though it had earlier been banned in most European countries.

Between 1880 and 1908, the search of IbsenStage indicates 402 records, but the actual performance number was probably even higher. ${ }^{3}$ It was so popular that all the European and American independent theatres staged it. Moreover, most of the famous international and the less famous regional travelling companies and performers also kept it in their repertoires. Although, usually, the high-artistic independent and the commercial international and regional travelling companies are treated separately, here, I argue for their close real and/or virtual interconnections, creating such a theatrical and cultural network, in which the local, the regional, the national and the transnational interacted with each other. At the turn of the nineteenth and twentieth centuries, such interaction among different forces and agents on different levels was one of the special features of cultural mobility, which characterized intercultural theatre culture, existing in Europe and America, and extending its influence almost all over the entire globe.

Though referring to the contemporary situation, Stephen Greenblatt argued in his book, Cultural Mobility: A Manifesto that "we need to understand

\footnotetext{
1 I would like to thank my two anonymous reviewers for their useful comments on an earlier version of this article.

2 Un. A. 1908, 12.

3 IbsenStage 2020.
} 
colonization, exile, emigration, wandering, contamination, and unintended consequences, along with the fierce compulsions of greed, longing, and restlessness, for it is these disruptive forces that principally shape the history and diffusion of identity and language, and not a rooted sense of cultural legitimacy." Although this kind of mobility has characterized Western culture since the ancient Greeks, as he reminds us, "literary and historical research has tended to ignore the extent to which, with very few exceptions, in matters of culture the local has always been irritated by the lager world." 5

All that is true even in places, he pointed out, that "at first glance are characterized more by homogeneity and stasis than by pluralism and change, cultural circuits facilitating motion are at work."6 This kind of global mobility is extended not only in space, but in time as well. As a result, he claimed that "a vital global cultural discourse then is quite ancient; only the increasingly settled and bureaucratised nature of academic institutions in the nineteenth and early twentieth centuries, conjoined with an ugly intensification of ethnocentrism, racism, and nationalism, produced the temporary illusion of sedentary, indigenous literary cultures making sporadic and half-hearted ventures toward the margins. The reality, for most of the past as once again for the present, is more about nomads than natives."7

When the intensification of nationalism occurred at the turn of the nineteenth and early twentieth centuries, however, there were intensive and detailed intercultural and transnational networks, connecting the seemingly separate national economies, cultures, and societies with each other. Focusing only on some key aspects, the investigation of the different stagings of Ibsen's Gengangere attempts to reveal the close interaction between nomads and natives, locals and the larger world within the seemingly separate theatre cultures of different Euro-American (national) states at the fin-de siècle. Using Ibsen and the independent theatres as pretexts, I would like to draw the attention to how local, regional, and national theatre cultures built upon and utilized the possibilities of cultural mobility, and thus worked parallel with and were interwoven by the inter- and transnational theatrical networks.

\section{Cultural Mobility, Censorship, and Ibsen}

Though Ibsen was one of the most popular authors at that time, his plays were often under a censorial ban. ${ }^{8}$ Working with official support and full institutional backing, censorship regarded the theatre as a possible dangerous institution, since, at that time, it was still a mass medium. Censors carefully observed plays and the theatres to prevent the portrayal of immoral conduct and often criticised the obscene and profane expressions and behaviour on stage. They prevented plays reaching the stage which touched on the taboos of the era (sexuality, adultery, abortion, female roles, patriarchy, etc.), and objected to

Greenblatt 2010, 2.

Greenblatt 2010, 4.

Greenblatt 2010, 5.

Greenblatt 2010, 5.

See Barstow 2001, 399. 
them, when their subjects were considered improper, based on religious, political, and ideological reasons. The ban of Ibsen's plays was part of a strategy by which the authorities of the European states attempted to prevent the free flow of information offered by the contemporary mediascape and cultural mobility, and therefore they attempted to control the possible new social and cultural formations offered by the anonymity of the metropolis and created by the economic possibilities of the capitalist free-market.

Among Ibsen's plays, ${ }^{9}$ Gengangere was especially problematic since it reflected on such contradictory issues as an illegitimate child, gender-roles, venereal disease, euthanasia, prostitution, the repressive church/religion, and offered radical solutions to them. ${ }^{10} \mathrm{lbsen}$ wrote it in Danish in the summer of 1881, published it in December in Copenhagen, and though a Danish travelling troupe premiered it in Danish in Chicago in 1882, it could not really find its way to the official public theatres. Instead, as Ståle Dingstad remarked about Scandinavia, "travelling theatre companies first performed the play."11 As a result, the first European premiere took place in Helsingborg, then a week later, it was also played in Copenhagen on 22 August 1883 by the travelling independent company of the Swedish actor-manager August Lindberg.

Lindberg's highly creditable production had at least seventy-five performances during the company's Scandinavian tour in 1883 and 1884 when he "eventually toured both the provinces and the capitals of all three Nordic countries." ${ }^{12}$ The Kungliga Dramatiska Teatern (Stockholm) held the premiere in the Autumn of 1883, then it was followed by Daniel Züberleins Selskab (30 September 1883), Olaus Olsens Theaterselkab (24 October 1883), and Nya Teatern/Svenska Teatern (2 November 1883). The number of these performances were, as Dingstad remarked, "well over 125", and "a conservative estimate of 400 spectators at each performance, easily calculates to over 50000 spectators." 13 While these theatre companies made Gengangere successful and cultural mobility possible in Scandinavia, the censorship of the European states attempted to prevent its staging and therefore restrict cultural mobility. Though there were sporadic performances earlier, ${ }^{14}$ the independent theatres offered a clever solution to get beyond the play's censorial ban, and therefore allow the free flow of cultural mobility.

9 See Ibsen's struggle with censorship Sova 2004.

10 See Mortensen 2007, Sova 2004, 98-101. The detailed explanation of the examiner of plays at the Lord Chamberlain's Office, Edward F. S. Pigott (Pigott 1892, 334).

11 Dingstad 2016, 126.

12 Marker and Marker 1996, 169.

13 Dingstad 2016, 127. See also Marker and Marker 1996.

14 Though the text was already available in German as early as 1881, it was not allowed to be played until 1886, when, on 14 April, the Ausburger Stadttheater staged it "as 'a dress rehearsal' for invited guests in a closed session" (Fischer-Lichte 2007, 62). In the same year, on 21 December, it was also staged by the Meininger Hoftheater without a ban, as censorship was exercised in the province by the leader of the theatre, prince Georg II. When, however, the company attempted to present it in Berlin as a guest-performance, the Berlin censor did not give his permission. See Koller 1965. 


\section{Gengangere in the Network of the Independent Theatres}

Among the independent theatres, Gengangere was first presented by the Freie Bühne in Berlin in 1889. Since public theatres were subjected to censorship, Ibsen had problems in Germany. The Freie Bühne, like its model, André Antoine's Théâtre Libre, however, was "a private association whose theatrical performances were open to members only, [thus it was] immune to the censorship that applied to public theatres." ${ }^{15}$ Being responsible for the theatrical programme of the Freie Bühne Verein, Otto Brahm chose Gespenster as its opening production, and presented it on 29 September 1889 at the Lessing Theater in Berlin. ${ }^{16}$ The Freie Bühne, as Erika FischerLichte explained, realized "a new concept of theatre, turning it into a forum where the most burning and topical questions of the day could be discussed publicly." 17 In terms of staging and acting, Gespenster also brought novelty to the theatre, and at the same time, it provoked a wide social debate over moral, social, cultural, and aesthetic issues. ${ }^{18}$

When, finally, the censor in 1894 dissolved the ban over Gespenster in the Prussian province, leading theatres followed the practice of the Freie Bühne, and competed to stage it. On 27 November 1894, there were two premiers in Berlin: one of them was staged by Otto Brahm, then the leader of the Deutsches Theater, the other was premiered at the Lessing Theater. ${ }^{19}$ The close relationship between the German theatre-makers and Antoine's theatre was demonstrated by the fact that, in October, the Théâtre Libre guest-performed the play at the Residenztheater in the city. The further popularity of the play in Germany can be seen in the fact that when, taking over the Deutsches Theater from Brahm, the ex-Brahm actor turned versatile director, Max Reinhardt, opened its new stage, the Kammerspiele in 1906, with Gespenster as its opening performance, but with a totally different theatrical concept. ${ }^{20}$ As a result, the staging of Ibsen's play by the Freie Bühne stimulated new stagings and theatre concepts, not to mention the problems which it offered the possibility to speak about publicly. At the same time, both Brahm and Reinhardt presented their productions on their international tours, and were seen in various European cities, among them, in Budapest. ${ }^{21}$

Though the Freie Bühne was modelled after the Théâtre Libre, Antoine's theatre staged Ibsen's play only after the Berlin premiere in 1890. Antoine had

15 Stark 1985, 334.

16 For Brahm, "the theatre served as a place where the dramatic poetry appeared absolutely subjugated to the writer's intentions, respecting all the words and ideas of the text, and cancelling all the improper theatrical effects." (Seidlin 1963, 139).

17 Fischer-Lichte 2007, 66.

18 On Brahm's ideas about Gespenster see Brahm 1915, 104-115.

19 Archer [1906], 2.

20 See Kahane 1984, and Fischer-Lichte 2007. Reinhardt asked the Norwegian painter, Edvard Munch to design the set, and created such an atmosphere on the stage with colour and lighting, in which the acting concentrated, as Erika Fischer-Lichte explained, "on the nerves - the nerves of the actors, the dramatic figures and the spectators" (Fischer-Lichte 2007, 72).

21 After Freie Bühne, there were companies that followed the same pattern: Max Halbe Intimes Theater, 1895, München; Freie Volksbühne, 1890, Berlin; Neue Freie Volksbühne, 1892, Berlin. See Miller 1931, 102-105. 
thought of the premiere of Ibsen's Les Revenants already in August 1888, and in a letter, sent to Francisque Sarcey, he mentioned that it was on the repertoire of the Hofftheater Meiningen. In January, next year, Emile Zola also drew Antoine's attention to the text, but he postponed the premiere as probably he was not satisfied with the translation. When the new translation appeared, from the Danish text, he staged it immediately, and even played Oswald in it.

At that time, French theatre was also under censorship, so out of necessity, the Théâtre Libre was open only to the members of its pre-paying society, "making the presentations 'private' events." ${ }^{2}$ One of the reasons Antoine established his theatre was the reform of the stage. In his theatre, Antoine got rid of the footlights, darkened the auditorium during the performance, introduced the technique of the so-called fourth wall, and asked his players to behave like in everyday life, as if the stage presented real time and space. His other aim was to present plays, which could not be played due to financial and/or censorial restrictions by the legitimate theatres. Envisaging a noncommercial theatre with active and engaged followers in France and abroad, the Théâtre Libre "unexpectedly forged a movement for theatrical renovation and created a focus for the public debate concerning the state of French theatre." ${ }^{23}$ Working between 1887 and 1895, it offered the possibility to reach the public and get beyond censorship with highly controversial issues by developing strategies based on the practices offered by the commercial market. As a result, it could serve as a viable model for other European and American independent theatres. ${ }^{24}$

After Berlin and Paris, Ghosts was also premiered in London in 1889 as the opening production of the Independent Theatre Society. A clerk for the Dutch East India Company and a freelance theatre critic, Jacob T. Grein and his companion, the critic and editor, C. W. Jarvis, established ITS after the Parisian model. They published their manifesto in The Weekly Comedy where they asked "what has been done in France, cannot it be done, too, in England? Is a British Théâtre Libre - a theatre free form the shackles of the censor, free from the fetters of convention, unhampered by financial considerations - is not such a theatre possible? That is the question." 25 Following Antoine and Brahm, Grein and Jarvis also ran their theatre as a private enterprise, which "must be founded by the cooperation of all who have the welfare of the drama at heart; [the performances] ought not to exceed two a month; [the actors] can be recruited from the huge crowd of the "disengaged", (...) and a stage can easily and cheaply be found in one of the many West-end halls, which have a licence for dramatic performances." 26

22 Goldstein 1998, 791.

23 Charnow 1998, 73. After Antoine's theatre, there were similar theatres that followed his pattern: Théâtre d'Art, 1891; Théâtre de l'OEuvre, 1893 and others.

24 See Waxman 1926.

25 Grein and Jarvis The Weekly Comedy 30.11.1889.

26 Grein and Jarvis The Weekly Comedy 30.11.1889. 


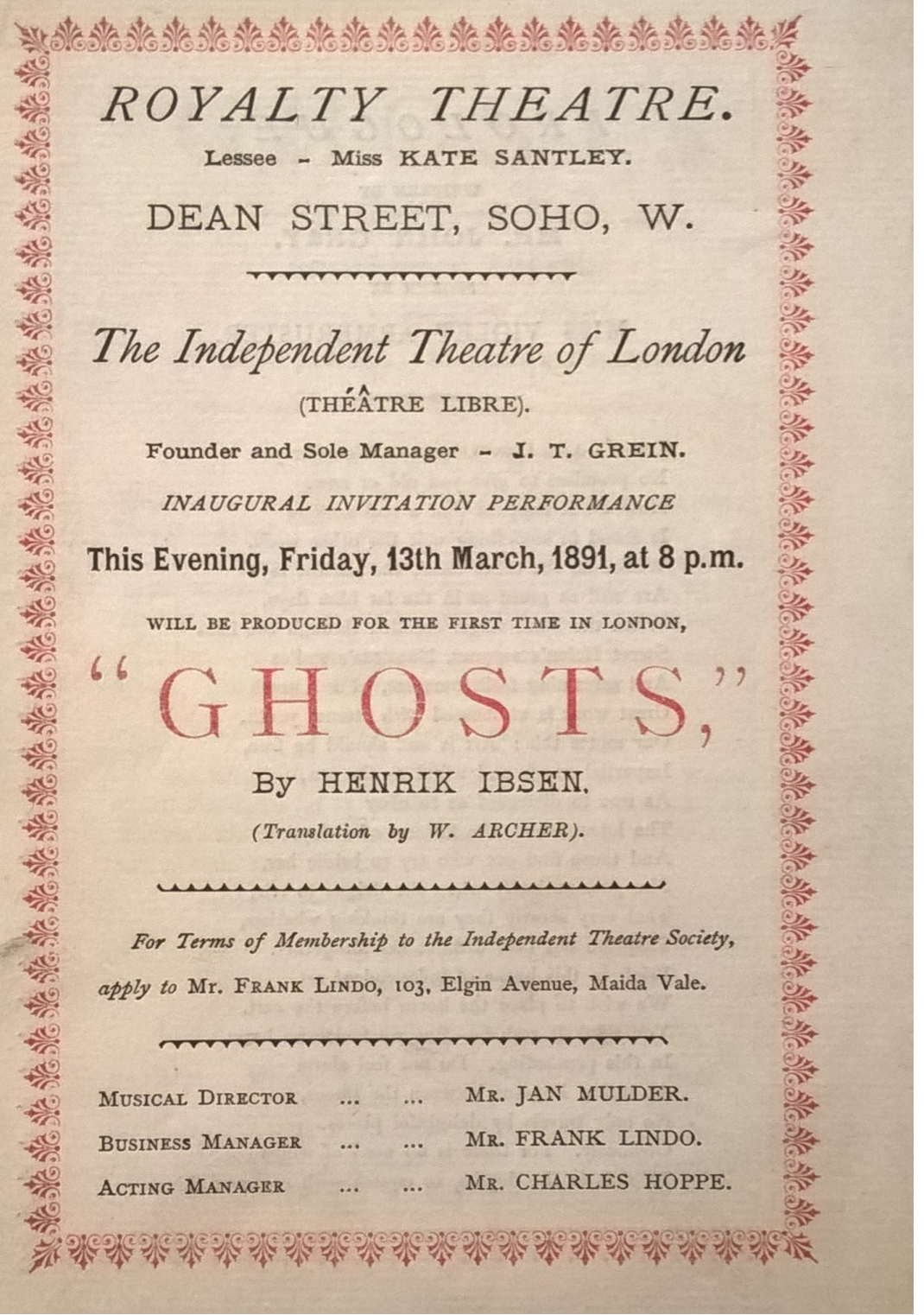

FIGURE 1. The playbill of the ITS in London, 1891.

To stage Ghosts, Grein contacted Kate Stanley, the general manager of the Royalty Theatre, who "gave permission for one performance of the play, on March 13, 1891, but she soon had misgivings about her decision and feared that she would lose her valuable theatre licence." 27 The Lord Chamberlain's Office did not interfere as it was a private endeavour, and despite the fact that interest was so high that Grein received more than three-thousand ticketrequests. The dubious status of the text "was accompanied by a media blitz that saturated the popular press for weeks before and after the performance and was witnessed by a packed audience of celebrities and up-coming literary as well as by playgoing hoi polloi." ${ }^{28}$ 
Though Ibsen's plays were not unknown in England, A Doll's House was premiered in 1889 for instance, ${ }^{29}$ the critical reaction to the production was passionate: more than five hundred articles appeared after the premiere in and beyond London in the English-speaking world. ${ }^{30}$ As Dawn B. Sova pointed out, "newspaper reviews the next day fanned the controversy as reviewers called the play 'a hideous nightmare', 'a morbid and sickening dissection of corrupt humanity', and 'a putrid drama the details of which cannot appear with any propriety in any column save those of a medical journal'." 31 The premiere's offense to public decorum was particularly obvious, "because it occurred through the theatrical medium, where the access of the popular audience was less restricted than it was to good literature, to medical treatises, or to political philosophy." 32 After the premiere, the ITS immediately became famous and notorious, as Catherine Wiley remarked, "for shocking realism, uninhibited by the censor's blue pencil" and most of the critics, apart from a few exceptions like G. B. Shaw and William Archer, reviled the production as in Clement Scott's words, as "a loathsome sore unbandaged, an open drain, a dirty act done publicly." 33 Though working for only six years until 1897, the ITS did not exist in vain as it initiated a theatrical reform in England and became one of the models for the future independent theatres of the Anglo-Saxon world. ${ }^{34}$

Spreading the news about the European models, ${ }^{35}$ especially about the ITS, the fever of the independent theatre soon reached the shores of the USA, where such theatres also appeared in the metropolises - New York, Boston, Washington - and "attracted an intelligent minority to the theatre." ${ }^{6}$ Ibsen had also an impact on the American experiments since the media kept reporting on his European premieres and their scandals. ${ }^{37}$ The New York premiere of Ghosts was held on 5 January 1894 at the Berkeley Lyceum Theatre. After the premiere, The New York Times remarked in general that Ibsen's "plots and the traits of his personages are unclean; his philosophy (...) is vicious. If accepted, it would not make men better." ${ }^{38}$ About the premiere, it mentioned that despite

29 As Kathrine E. Kelly explained that "Ibsen's plays began appearing in England between 1876 and 1888 as both published texts and performances, many of them amateur, and some very loose adaptations" (Kelly 2008, 12).

30 See for instance B. F.'s article about the Grein's Independent Theatre in London at The New York Times on 15 March 1891 (B. F. The New York Times 15.3.1891).

31 Sova 2004, 100. See also Un. A. The Era 21.3.1891.

32 Davis 1990, 449.

33 Quoted in Wiley 1990, 442-443.

34 Similar companies: Stage Society, 1899; Elizabethan Stage Society, 1881; The Pioneers Players, 1905; The New Century Theatre, 1906; The Play Actors Society, 1907; and later, The Fellowship of Players; The International Theatre Society; English Drama Society; Glasgow Players League Club, and others.

35 See for instance B. F. The New York Times 15.3.1891.

36 Hatlen 1963, 141. The American independent theatres: Boston Independent Theatre Association, 1891; The New York Theatre of Arts and Letters, 1892-1893 ; Standard Company of Actors (only theoretically), 1895; Criterion Independent Theatre, 1897; A Course of New Plays, 1899-1900 and others.

37 See for instance B. F. The New York Times 15.3.1891.

38 Un. A. The New York Times 6.1.1894. 
the modifications of the text ("one of Frau Alving's awful speeches had been cut out", for instance), "the horror was all there." 39 Finally, the review concluded that "morally speaking, it is like an 'anatomical museum'". ${ }^{40}$ The alterations of the text and the negative reactions, however, did not deter an interested public.

Due to huge demand, the company repeated the performance a few weeks later on 25 January at the Garden Theater. However, Ibsen and his Ghosts did not receive better treatment. The critic, William Winter wrote in The New York Tribune on the following day "that a three-act dialogue called "Ghosts" being one of the most unpleasant of the many unpleasant productions of the Norwegian crank, Mr. Ibsen, - was obtruded upon the public notice yesterday afternoon at the Garden Theatre, where it bored a small audience during the several wasted hours." ${ }^{11}$ Then he added that "Mr. Ibsen's abominable stuff, which is both dull and dirty, will never prosper in this capital." 42 Though he was not right, these reactions reveal that Ibsen's reception was as hostile in America as on the European continent. Likewise, as with their European counterparts, it was the American independent theatres who were the first to attempt to stage Ibsen's plays - First Independent Theatre Association, 1981, Boston; Criterion Independent Theatre, 1897, New York; and others.

The new spirit of the independent theatres and Ibsen spread not only Westwards, but Eastwards as well. ${ }^{43}$ In Russia, for instance, having been also under a ban, Ibsen's Привиде́ния was premiered on 7 January 1904 by the Театр Неметти (Teatr Nemetti) at St. Petersburg. In the same year, on 24 October, it was also staged at the Драматический театр Веры Фёдоровны Комиссаржевской (Dramaticheskij Teatr Very Fjodorovny Komissarzhevskoi). The premiere of the Московский Художественный Театр (MXAT) was held in the following year, on 5 February 1905 (31 March), and directed by Konstantin Stanislavski. In 1898, Stanislavski and Vladimir Nemirovich-Danchenko established the MXAT after Antoine's Parisian model, which Stanislavski had seen on his trips to Paris. ${ }^{44}$ The premiere was also hit by censorship, as Stanislavski's Diary tells us that "Levin informed the actors what had been cut out by the censor." 45

Like the Meininger Hoftheater, ${ }^{46}$ seen by Stanislavski in Moscow in 1890 , he also attempted to create a Norwegian milieu in his staging. He sent his detailed instructions to the set designer, as Nick Worrall claimed, since he wanted to achieve "a degree of national and geographical authenticity," 47 and

39 Un. A. The New York Times 6.1.1894.

40 Un. A. The New York Times 6.1.1894. See also E. A. D. The New York Times 7.1.1894.

41 Quoted in Hatlen 1963, 139.

42 Quoted in Hatlen 1963, 139.

43 It was premiered, for instance, in Zagreb on 1 October 1896 by the Zagreb Hrvatsko Narodno Kazalište U Zagrebu; in Bucharest, Romania on 1 March 1897 by the Teatrul Naţional Bucuresti; in Belgrade, Serbia on 5 June 1904 by the Narodno Pozorište U Beograda; in Prague on 24 February 1909 by the Národni Divadlo; in Kasanlak, Bulgaria on 21 October 1902 by the Savremen Teatar; in Sofia, Bulgaria on 16 October 1904 by the Naroden Teatar, for more results see IbsenStage.

44 Benedetti 1989, 17-18; Carnicke 2000, 29 and Leach 2004, 13.

45 Stanislavski $1964,38$.

46 See Koller 1984, 193-194.

47 Worrall 1996, 163. 
brought motifs to the stage, which were considered by his contemporaries as authentically Norwegian. ${ }^{48}$ In the performance, Oswald was played by Ivan Mikhailovich Moskvin, who "was to appear 'a being of crystalline purity' imbued with love of life - someone whose death was a beautiful, 'premature conclusion' to it." 49 His mother, Mrs Alving was played by one of the leading actresses of the company, Margarita Georgievna Savitskaya. Stanislavski asked her "to play a carefree, playful, elegant French woman with a drama in her past,"50 and she had to play the role in, "what he called 'the French style', relying on facial expression and voice intonation, with a minimum gesture." ${ }^{51}$ Stanislavski embedded his Ibsen-premiere among similar foreign and Russian authors and presented it in his usual realistic staging.

After the European, American, and Russian premiers, Ibsen's text, Kísértetek was also staged in Budapest on 17 October 1908 by an independent theatre, the Thália Társaság. Following East- and West-European independent theatre models, László Bánóczy, Marcell Benedek, György Lukács, and Sándor Hevesi initiated the Thália with two aims: to renew the Hungarian dramatic canon, "occasionally performing such old and new plays which cannot be found in the repertoires of theatres of the capital, but which possess great artistic or cultural values and interests"; and to renew by the Society's own efforts and resources the staging of these plays "in which professional actors or actors under contract cannot take part." 52 The Thália presented plays by Hauptmann, Ibsen, Strindberg, Wedekind, Gorky, and others, in the translations of the members of its Society, and simultaneously propagated new Hungarian plays. The company consisted of amateurs and young professionals, educated in the Thália's school and trained by the director, Sándor Hevesi, during a relatively long rehearsal period (often more than two months).

Though the realist principles on acting and staging appeared in the staging of Kisértetek, one of the reviews remarked that the Thália played "on a tiny stage, in a dingy set, in an absolutely in-adequate place for its aims and achievements, in the cold and unfriendly room of the Népszínpad [Volksbühne] at the outskirt of Budapest." 53 In spite of these circumstances, the Pesti Hírlap remarked that "the directing was careful and in style." ${ }^{54}$ Apart from the problems, caused by the lack of appropriate venues and financial backing, the authorities were also hostile towards the Thália, since, like its European and American counterparts, it presented the major taboos and the most controversial issues of contemporary civic life. Though closed down in 1908, the Thália envisioned theatre as a social-critical forum, investigating the social, moral, economic and cultural relations of society. At the same time, it also recreated theatre as a political institution by presenting plays to the most underprivileged part of society, the workers.

48 See Stanislavski 1964, 28.

49 Worrall 1996, 163.

50 Stanislavski 1964, 27.

51 Worrall 1996, 163.

52 Gábor 1988, 64.

53 (E.) Pesti Napló 18.10.1908.

54 Un. A. Pesti Hírlap 18.10.1908. 
Though the Kisértetek was one the last premieres of the Thália before its final dissolvement, they played it ten times, especially on their tour in the provinces. ${ }^{55}$ The critic, Ignotus remarked that the Thália "has just given Ibsen's Kísértetek, and it was much better than Zacconi's, though Tihanyi, who played Oswald, was very good, he was not a genius like Zacconi." ${ }^{66}$ Ignotus's review did not refer to Ibsen as a novelty, as his plays had already been staged in Budapest, ${ }^{57}$ and his Kísértetek did not make a scandal either, though he also remarked, as the critic of the Pesti Napló, that Ibsen's text "was played for the first time in Hungarian by the Thália." 58 Moreover, referring to the international travelling star, Ermete Zacconi, Ignotus drew attention to the frequent appearance of foreign guest-performances in Budapest.

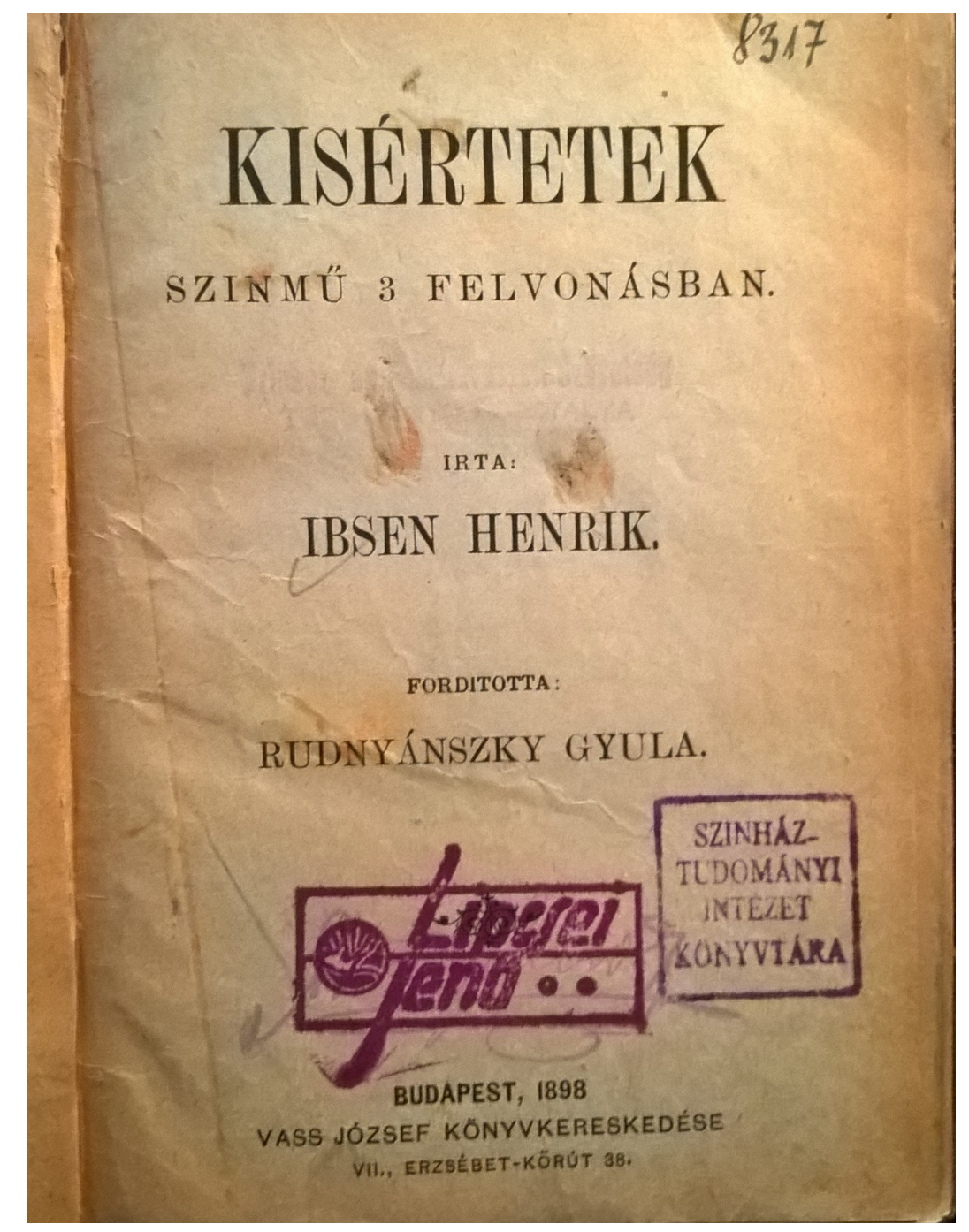

FIGURE 2. The title page of the first Hungarian translation of Ibsen's Gengangere, 1898.

55 Its Hungarian translation by Gyula Rudnyánszky was published as early as 1898 see Figure 2. 56 Ignotus Nyugat 21/1908.

57 The National Theatre for instance premiered Nóra (Et dukkehjem) in 1889, then A társadalom támaszai (Samfundets stötter) in 1890, A népgyülölő (En folkefiende) in 1891, and John Gabriel Borkman in 1898.

58 Un. A. Pesti Hírlap 18.10.1908. 
Apart from staging Ibsen's Gengangere, the above briefly mentioned independent theatres staged plays which "presented candidly on the stage themes that were considered taboo", 59 introduced new methods of staging and acting, and altered the known formula of the well-made-play of the commercial theatres. They, as Richard Hornby pointed out, "operated on a subscription system [with its economic advantages and as] a way around government censorship, since [they] could assert the legal fiction of being merely private clubs, not open to the public." 60 Antoine's theatre never played the same production more than three times, the Freie Bühne, the ITS, and the Thália rented theatre venues especially for their matinee productions when the commercial theatres were not allowed to play. Though the independent theatres worked beyond the structure of the existing commercial and official theatres and beyond the territory of censorship, the plays presented, and their stagings, had a fruitful impact on the entire theatre sector. ${ }^{61}$

The investigation of the various stagings of Ibsen's Gengangere reveals that though these theatres were independent, they were also directly, sometimes in person, and/or indirectly through the contemporary mediascape, connected to each other by sharing their working and organizational systems, repertoires, and their staging and acting methods. ${ }^{62}$ Apart from these common features, they were all interested in touring. Due to financial reasons, Antoine's Théâtre Libre, for instance, "began to rely on extensive touring to make up deficits; the summer of 1892 saw trips to Holland, Belgium, Bordeaux, Nantes, Rouen, and Le Havre." 63 The practice of touring regionally and/or internationally was later followed by the Freie Bühne, the Thália, the American independent theatres, and the Independent Theatre Society, which, for instance, later in London, played host "to four performances by Lugné-Poë's Théâtre de l'@Euvre." ${ }^{4} 4$ As a result, the independent theatres created - more or less - an international real and/or virtual network. And if they had not known each other in person, the contemporary mediascape (Appadurai) took care that their activities, especially their scandals, got beyond the existing national borders. ${ }^{65}$

\section{Ibsen's Plays in the Network of Independent and Travelling Theatres - Fin- de-Siècle Theatre System}

The network of the independent theatres, however, was supplemented by

59 Ballard, 7.

60 Hornby 2009, 296.

61 The National Theatre in Budapest played Ibsen's Kísértetek on 10 December 1909, nearly one year later than the Thália. After that, however, the following premier was first held again on 11 March 1927, and then the next one on 24 February 1935. After that, there was a forty-eight-year pause as the following premier took place again on 11 February 1983.

62 The English theatre critic and translator, William Archer, for instance, had a campaign for Ibsen in the Anglo-Saxon theatre. He wrote extensively both publicly and in private letters, and gave numerous lectures about Ibsen's plays and their European premiers. He was one of the first critics who reviewed the 1883 production of the Kungliga Dramatiska Teatern for the Englishspeaking world (Archer 1883, 455-460, and see also Postlewait 1986).

63 Ballard, 22.

64 Ballard, 54

65 See Shepherd-Barr 1997, Davis 1990 and Postlewait 1986. 
and interwoven with the networks of the international and regional travelling groups and (star-)performers. ${ }^{66}$ In Budapest, for instance, as Ignotus's review indicated above, the Kísértetek had already been known by audiences before the Thália played it. Partly, the Hungarian press kept reporting on its European premieres, especially about their scandals. ${ }^{67}$ Partly, the travelling groups/stars, Ignotus mentioned only Zacconi, often played it in Budapest. ${ }^{68}$ In Budapest, the international travelling-stars presented not only the Kísértetek, but Ibsen's other plays as well. ${ }^{69}$ Their guest-performances highlight that at that time Budapest was part of the theatrical network of the international travelling stars. Budapest, however, was not a special case, as the tours of these guest-performers connected nearly all European metropolises. As a result, European theatre was connected not only by the managers of the commercial theatres ${ }^{70}$ and the independent theatres, but also by the travelling groups/performers who offered plays, staging methods, and working conditions to the local theatres and the smaller travelling theatres playing in the vernacular to local audiences. ${ }^{71}$

As a result, Hungarian-speaking audiences in the provinces of the AustroHungarian Monarchy, for instance, were introduced to Ibsen's (and to other contemporary) plays, since, similar to the tours of Thália, the tours of Scandinavian theatre groups, the independent theatres, and the international travelling stars, mentioned earlier, ${ }^{72}$ regional travelling troupes played them in the major cities, often inviting a star-performer from the theatres of the capital. The IbsenStage reports twenty-eight such records of these performances, but the number of these guest-performances was probably higher. As it stands,

66 See their connection in Carlson 1961.

67 See these articles in Gábor 1988, 345-384.

68 Like Ermete Zacconi (1897, 1898-1899, 1907), Ermete Novelli (1900), the Berliner Secessionbühne (1900) and the Deutsches Theater (1901).

69 Between 1892 and 1907, Eleonora Duse $(1892,1907)$, Sarah Bernhardt (1893), Ermete Zacconi $(1897,1898,1907)$, Italia Vitaliani (1898), Ermete Novelli (1900), the Deutsches Theater (1901, 1902, 1903), the Lessing Theater (1905) and Suzanne Deprès $(1906,1907)$ visited the city. Most often they played Nóra (Et dukkehjem) (Duse, 1892; Bernhardt, 1893; Deutsches Theater, 1903; Lessing Theater, 1905; Deprès, 1906, 1907), but they kept Hedda Gabler (Vitaliani, 1898), a Vadkacsa (Vildanden) (Deutsches Theater, 1902), A nép ellensége (En folkefiende) (Lessing Theater, 1905), A tenger asszonya (Fruen fra havet) (Lessing Theater, 1905), and Rosmersholm (Duse, 1907) in their repertoires.

70 See Balme 2005, 2007; Sorba 2006; Leonhardt 2013, 2014; Imre 2013; Schweitzer 2015.

71 Even local, state-sponsored, official theatres contributed to Ibsen's fame, like the National Theatre in Budapest, for instance, working in such a local milieu, which was inspired by the independent theatres and travelling companies, and which, due to the compelling force of the milieu and/or open-minded theatre-managers with a European horizon, sooner or later produced Ibsen's texts on their stages. See the Ibsen's production at the National Theatre, Budapest: Nóra (Et dukkehjem, 1889); A társadalom támaszai (Samfundets stutter, 1890); A népgyülölö (En folkefiende, 1891); John Gabriel Borkman (1898); Hedda Gabler (1907). Except Nóra (Et dukkehjem), the other productions were played rarely with long pauses between them. After its 1891 premiere, A népgyülölő (En folkefiende), for instance, was restaged there again only in 1974. 72 Ståle Dingstad mentions that in Scandinavia, traveling theatre companies performed the play in Sweden, Denmark, Norway, and Finland, and these theatres "were not for the few but for the many: they included people from different social, economic, and cultural classes far beyond the avant-garde and the bourgeoise" (Dingstad 2016, 127-128). 
fifteen companies ${ }^{73}$ played the Kísértetek in twenty four cities ${ }^{74}$ with young, but already relatively famous male guest-performers from Budapest. ${ }^{75}$ Although the role these companies played is quite underappreciated in theatre research, ${ }^{76}$ it seems that Ibsen's Kísértetek (and his other, and other contemporary playwrights' plays) was/were known by the Hungarian-speaking citizens of the Austro-Hungarian Monarchy - both in the capital and in the provinces -, since, apart from the actual performances, the press also spread news about them. ${ }^{77}$

Speaking of the Hungarian theatre sector, but I suppose that in this respect the situation was similar in each European country at that time, its theatrical system developed not only within its national borders and language barriers, but also participated in the European theatre- and touring-system as a host and as a provider of goods (plays, productions, players, staging methods, etc.) for the international theatre market. The various guest-performances in the European metropolises draws attention to the fact that by the end of the nineteenth century, there were well-organized touring-systems in Europe, which soon extended their influence over the American continent and the Far-East. ${ }^{78}$

Investigating Ibsen's Et dukkehjem (ADoll's House), Julie Holledge, Jonathan Bollen, Frode Helland, and Joanne Tompkins claimed, in their book, A Global Doll's House, that, apart from the various translations of the text, "the first global expansion of Et dukkehjem happens at the end of the nineteenth century: fourteen major international touring productions in eleven European languages travel to thirty-five countries over five continents." 79 They also remarked that, "except for a Japanese production, all the tours originated in Europe and followed global flows of European migration; they used the shipping, rail, and road networks to traverse the trade routes that linked European nations with their colonial settlements and diasporas. (...) By the 1920s, these global touring circuits reached their geographical limits. The only overlap between these tours happened in cosmopolitan cities (New York, St Petersburg, Montevideo, Rio de Janeiro, Istanbul), where performances were given in three or more

73 Like the company of Kálmán Egry and Antal Déky Antal, Miklós Kúnhegyi, Dezső Tihanyi, Ignác Krecsányi, András Leszkai, Lajos Szalkay, István Relle and others (See IbsenStage 2020). 74 Cities where Hungarian-speaking communities lived like Kolozsvár (now Cluj Napoca, Romania), Sepsiszentgyörgy (now Sfântu Gheorge, Romania), Szatmárnémeti (now Satu Mare, Romania), Pécs, Hódmezővásárhely, Szeged, Arad, Miskolc, Pozsony, Zombor (now Sombor, Serbia), Zenta (now Senta, Serbia), Óbecse (now Opština Becej, Serbia), Pozsony (now Bratislava, Slovakia), Győr, Pápa, Székesfehérvár, and others, see IbsenStage 2020.

75 Only five actors shared the role of Oswald: Jenő Ivánfi, László Bakó, Oszkár Beregi, Artúr Somlay and Jenö Könyves.

76 I think, sooner or later, it will be crucial to undertake research about the impact and the network of these travelling companies throughout Europe.

77 See the collected articles written about the Thália Társaság in national papers in the AustroHungarian Monarchy in Gábor 1988, 345-379. These articles usually refer to the other European independent theatres, mostly to the Freie Bühne and the Théâtre Libre.

78 One of the first European touring companies was the Meininger Hoftheater, which visited Berlin as early as 1874 . They also went to other German and European cities. In 1888 , for instance, they guest-performed in Brussels, where "Antoine viewed their performances especially (...) to observe their treatment of the crowd" (Carlson 1961, 247).

79 Holledge, Bollen, Helland and Tompkins 2016, 24. 
languages." ${ }^{80}$ As a result, although by the end of the nineteenth century, the theatrical market of the world was still divided by national, geographical, and language borders, the touring-system of the commercial theatres was fully established, and offered the opportunity to establish truly international stars, like Sarah Bernhardt, Eleonora Duse, Tommaso Salvini, Ermete Zacconi, or Ermete Novelli. ${ }^{81}$

Investigating the world-wide fame of Et dukkehjem, Holland and her colleagues also reminded us that until now "the activities of the early European Noras have received little attention in comparison with the more familiar story of the struggle for symbolic power waged by Ibsen's male „brokers” in the independent theatres of Paris, Berlin, and London." 82 Although the special power and influence of the female theatre-managers was short lived, as they were soon and quickly forgotten, they are absolutely right as Ibsen's international fame was due not only to the independent theatre movement, but also due to those travelling companies which were led mostly by female managers/players like Duse, Bernhardt, or Gabriela Zapolska, Agnes Sorma, Betty Hennings, Suzanne Després, Janet Achurch and many more. ${ }^{83}$

In general, the female star-performers' influence over Ibsen's popularity is true, especially when we take into consideration the texts with significant female roles, but Gengangere was an exception. Contemporaries regarded it as a play in which the male role, Oswald is the most significant, and not the female characters - Mrs Alving and Regina. As a result, the female-manager-led travelling companies did not often play it, but it was one of the most important Ibsen-productions of the male-managers. It was in the repertoire of Zacconi, Salvini, Moissi, and the local male guest-stars, like the Hungarian-speaking ones: Jenő Ivánfy, Oszkár Beregi, Artúr Somlay, and others. The spreading of Gengangere was thus closely tied partly to the independent theatres and partly to the male-led local/regional and inter/national travelling companies.

\section{Conclusions: Cultural Mobility, Theatre Networks, and Theatre Historiography} The interconnected networks of the independent theatres, the local/regional, and the inter/national travelling companies draw attention to the fact that it is high time to expand the horizons of national theatre histor(iograph)ies toward the local/regional and, at the same time, European and even globally transnational perspectives. From at least the middle of the nineteenth century, European theatre cultures have established their working conditions within transnational/

80 Holledge, Bollen, Helland and Tompkins 2016, 30-31.

81 Gengangere as Gli Spettri was one of the favourite pieces of both Zacconi and Novelli and they played it in nearly all the European metropolises. Other European theatres also utilised the toursystem: the Wiener Burgtheater for instance visited Berlin in 1905 with the piece, in which Agnes Sorma played Mrs Alving, while Joseph Kainz played Oswald. Having been declared bankrupt, Antoine also went touring, they played in Belgium, Italy, and Germany. They guest-performed the piece in Berlin in October 1905 (see Charnow 1998, 85).

82 Holledge, Bollen, Helland and Tompkins 2016, 28.

83 See Holledge, Bollen, Helland and Tompkins 2016, 28-35. Regarding the connection between the touring stars and the local theatre culture see, for instance, Gagen 2010 and Papageorgiou 2008. 
intercultural contexts, based on a commercial market economy and global high and popular culture, even if they themselves did not step over their national borders. At the same time, we should pay much more attention to local and regional theatrical activities on an intracultural level, ${ }^{84}$ which were carried out most of the time beyond and bellow the major theatrical institutions of the capitals and the metropolises. As a result, national theatre history(iograph)ies must widen their horizon towards the integration of both the global/transnational and local/regional theatrical tendencies. Without taking into consideration the trans/inter- and intracultural connections of these territories, it is nearly impossible to interpret national theatrical tendencies, since the development of the theatres on a national level occured interconnectedly with the tendencies on the transnational/intercultural and intracultural levels, and they were all heavily influenced by each other. ${ }^{85}$ As a result, I am afraid to say, it is not good news for the nationalists as locals always kept interacting with the nomads on a local, regional, national, and transnational level not only at the fin-de-siècle, but earlier, and, hopefully, in the future as well.

\section{AUTHOR}

Zoltán Imre received his PhD from Queen Mary College, University of London (2005) and is now an associate professor in the Department of Comparative Literature and Culture, Eötvös Loránd University, Budapest. His publications include various articles and books like Alternative Theatre Histories (editor, author, 2008), Staging Theatre - Theories, Histories, and Alternatives (2009), Staging the Nation - The Changing Concept of the Hungarian National Theatre from 1837 until today (2013), Staging the Other - The Inter- and Intracultural Connections of the Hungarian Theatre (2018) on Hungarian and European theatre. See https://elte-hu.academia.edu/ImreZoltan.

84 About intracultural theatre see Bharucha 2000, 1-19.

85 See Balme and Leonhardt 2016, 1-9; Schweitzer, 2015; Wilkie 2015; Leonhardt 2014, 2-22; Leonhardt 2013, 50-63; Schweitzer 2012, 241-267; Balme 20007 and Werry 2005, 355-382. 


\section{REFERENCES}

Archer, William. 1906. "Introduction to Ghosts by Henrik Ibsen." Loyal Books website, http:// www.loyalbooks.com/book/Ghosts-Henrik-lbsen (24.2.2020).

Ballard, James. The Independent Theatre Movement in Europe and the Influence of Henrik Ibsen. Dissertation. The University of London Computer Center, Mahara, mahara.ulcc.ac.uk/ view/view.php?id=9.

Balme, Christopher B. and Nic Leonhardt. 2016. "Introduction: Theatrical Trade Routes." Journal of Global Theatre History 1, 1-9.

Balme, Christopher B. 2005. "Selling the Bird: Richard Walton Tully's The Bird of Paradise and the Dynamics of Theatrical Commodification." Theatre Journal 1, 1-20.

Balme, Christopher B. 2007. Pacific Performances - Theatricality and Cross-Cultural Encounter in the South Seas. London: Palgrave Macmillan.

Barstow, Susan Torrey. 2001. "Hedda Is All of Us': Late-Victorian Women at the Matinee." Victorian Studies 1, 387-412.

Benedetti, Jean. 1989. Stanislavski: An Introduction. London: Methuen.

Bharucha, Rustom. 2000. The Politics of Cultural Practice - Thinking Through Theatre in an Age of Globalization. London: Athlone.

Brahm, Otto. 1915. Kritische Schriften - Erster band: Über Drama und Theater. Berlin: S. Fischer.

Carlson, Marvin. 1961. "Meiningen Crowd Scenes and the Théâtre Libre." Educational Theatre Journal 4, 245-249.

Carnicke, Sharon M. 2000. "Stanislavsky's System: Pathways for the Actor." In Alison Hodg (ed.). Twentieth-Century Actor Training. London and New York: Routledge, 11-36.

Charnow, Sally. 2000. "Commercial Culture and Modernist Theatre in Fin-de-Siècle Paris: André Antoine and the Théâtre Libre." Radical History Review 3, 60-90.

Davis, Tracy C. 1990. “The Independent Society's Revolutionary Scheme for an Uncommercial Theatre." Theatre Journal 4, 447-454.

Dingstad, Ståle. 2016. "Ibsen and the Modern Breakthrough - The Earliest Productions of The Pillars of Society, A Doll's House, and Ghosts." Ibsen Studies 2, 103-140.

Fischer-Lichte, Erika. 2007. "Ibsen's Ghosts - A Play for All Theatre Concepts? Some Remarks on Its Performance History in Germany." Ibsen Studies 7, 61-83.

Gábor, Éva. (ed.) 1988. A Thália Társaság 1904-1908. Levelek és dokumentumok. Budapest: Magyar Színházi Intézet - MTA Lukács Archívum és Könyvtár. 
Gagen, Derek. 2010. "Spanish Theatre in Argentina: Margarita Xirgu's 1937 Tour and the Commemoration of Lorca." Hispanic Research Journal 3, 210-226.

Goldstein, Robert Justin. 1998. "Fighting French Censorship, 1815-1881." The French Review 3, 785-796.

Greenblatt, Stephen. 2010. Cultural Mobility: A Manifesto. Cambridge: Cambridge University Press.

Hatlen, Theodor. 1963. "The Independent Theatre Movement in New York, 1890-1900." Educational Theatre Journal 2, 136-142.

Holledge, Julie, Jonathan Bollen, Frode Helland and Joanna Tompkins. 2016. A Global Doll's House, Ibsen and Distant Visions. London: Palgrave Macmillan.

Hornby, Richard. 2009. "Somewhere Else First'." The Hudson Review 2, 296-302.

Imre, Zoltán. 2013. "Operetta Beyond Borders: The Different Version of Die Csárdásfürstin in Europe and the United States (1915-1921)." Studies in Musical Theatre 2, 175-205.

Kahane, Arthur. 1984. "Edvard Munch and Gustav Knina." In Knut Boeser, Renata Vatkova, (eds.). Max Reinhardt in Berlin. Berlin: Fröhlich and Kaufmann, 265-276.

Kelly, Kathrine E. 2008. "Pandemic and Performance, Ibsen and the Outbreak of Modernism." South Central Review 1, 12-35.

Koller, Ann Marie. 1965. "Ibsen and the Meiningers." Educational Theatre Journal 2, 101-110.

Koller, Ann Marie. 1984. The Theater Duke - Georg II of Saxe-Meiningen and the German Stage. Stanford: Stanford University Press.

Leach, Robert. 2004. Makers of Modern Theatre: An Introduction. London: Routledge.

Leonhardt, Nic. 2013. "A Hop, A Frock, A Hairdo: Irene Castle and her Female Networks of Theatrical Business." Popular Entertainment Studies 1, 50-63.

Leonhardt, Nic. 2014. "Transatlantic Theatrical Traces: Oceanic Trade Routes and Globetrotting Amusement Explorers." The Passing Show - Newsletter of the Schubert Archive 1, 2-22.

Marker, Frederick J. and Lise-Lone Marker. 1996. A History of Scandinavian Theatre. Cambridge: Cambridge University Press.

Mortensen, Ellen. 2007. "Ibsen and the Scandalous: Ghosts and Hedda Gabler." Ibsen Studies 2, 169-187.

Papageorgiou, Ionna. 2008. "Adelaide Ristori's Tour of the East-Mediterraneaum (1864-1865)." Theatre Research International 2, 161-175.

Pigott, Edward F. S. 1892. Report from the Select Committee on Theatres and Places of 
Entertainment together with the Proceedings of the Committee, Minutes of Evidence, Appendix, and Index. London: Her Majesty's Stationery Office, 334-335.

Postlewait, Thomas. 1986. Prophet of the New Drama. William Archer and the Ibsen Campaign. Westport (CT): Greenwood Press.

Schweitzer, Marlis. 2012. "Networking the Waves: Ocean Liners, Impresarios, and Broadway's Atlantic Expansion." Theatre Survey 3, 241-267.

Schweitzer, Marlis. 2015. Transatlantic Broadway: The Infrastructural Politics of Global Performance. London and New York: Palgrave Macmillan.

Seidlin, Oscar. 1963. "Otto Brahm.” The German Quarterly 2, 131-140.

Shepherd-Barr, Kirsten. 1997. Ibsen and Early Modernist Theatre, 1890-1900. Westport (CT): Greenwood Press.

Sorba, Carlotta. 2006. "The Origins of the Entertainment Industry: the Operetta in Late Nineteenth Century Italy." Journal of Modern Italian Studies 3, 282-302.

Sova, Dawn B. 2004. Banned Plays - Censorship Histories of 125 Stage Dramas. New York: Facts on File.

Stanislavski, Konstantin. 1964. "Director's Diary, 1905, The MAXT Production of Ibsen's Ghosts." The Tulane Drama Review 1, 26-41.

Stark, Garry D. 1985. "The Censorship of Literary Naturalism, 1885-1895: Prussia and Saxony." Central European History 3-4, 326-343.

Waxman, Samuel Montefiore. 1926. Antoine and the Théâtre Libre. Cambridge: Harvard University Press.

Werry, Margaret. 2005. “"The Greatest Show on Earth”: Political Spectacle, Spectacular Politics, and the American Pacific." Theatre Journal 3, 355-382.

Wiley, Catharine. 1990. "Staging Infanticide. The Refusal of Representation in Elizabeth Robins' Alan's Wife.” Theatre Journal 4, 432-446.

Wilkie, Fiona. 2015. Performance, Transport and Mobility - Making Passage. London: Palgrave Macmillan.

Worrall, Nick. 1996. The Moscow Art Theatre. London and New York: Routledge.

\section{Newspapers and journals}

B. F. 1891. "New Ideas on the Stage - Mr. Grein's Independent Theatre in London." The New York Times 15.3.1891, 1.

(E.). 1908. "Thália." Pesti Napló 18.10.1908, 12. 
E. A. D. 1894. "The Week at the Theatres - Decent Folks Had To Blush, But Good Acting Was Done." The New York Times 7.1.1894, 6.

Grein, J. T. and C. W. Jarvis. 1889. "A British „Theatre Libre” (A Suggestion).” The Weekly Comedy 30.11.1889, 18.

Ignotus. 1908. "Thália rediviva." Nyugat 21/1908, http://epa.oszk.hu/00000/00022/00020/00444. $\mathrm{htm}(24.2 .2020)$.

Un. A. 1891. “"Ghosts”.” The Era 21.3.1891, 10.

Un. A. 1894. "Ibsen in English Again. A Surprisingly Able Performance of „Ghosts” at the Berkeley Lyceum." The New York Times 6.1.1894, 8.

Un. A. 1908. "A Thália új hajlékában - A „Kísértetek”." Népszava 21.10.1908, 12.

Un. A. 1908. "Without Title." Pesti Hírlap 18.10.1908, 10.

\section{Archives and websites}

Archer, William. 1883. Ibseniana - Transcripts of Lectures and Letters by William Archer. Victoria \& Albert Museum, Theatre and Performance Collections, London, GB71 THM/368/1/5/9.

IbsenStage - The Ibsen Stage Performance Database, https://ibsenstage.hf.uio.no 